in the results is one of fundamental importance. Berson's numbers clearly do not go to the end of the matter, for with a little play of the imagination in the region of extrapolation, his results bring absolute zero within sight at the very moderate height of some thirty miles, whereas $-68^{\circ} \mathrm{C}$. is the lowest temperature recorded in the flight of the unmanned balloon Cirrus from Berlin, which is reported to have reached a height of $\mathrm{I} 8,000$ metres. This, by a curious coincidence, is identical with the lowest temperature recorded at the earth's surface. It was registered at Werchojansk, in Siberia, on January 15,1885 ; a still lower temperature, $-70^{\circ} \mathrm{C}$., is given in the Meteorologische Zeitschrift for June as registered by the apparatus of an unmanned balloon started from Vienna on January to of last year. Kite observations also afford information as to the rate of fall of temperature under varied meteorological conditions. But the height which they can attain does not give them a final voice in the determination of the question of the lowest limit of atmospheric temperature.

Another quantity for the determination of which balloon observations are specially appropriate is the constant of solar radiation, but the results are not yet final and the subject is too wide for this occasion.

It would be a matter for congratulation if Glaisher's exploration of the upper air could be continued by his own countrymen. Investigations have, indeed, been made recently by the Rev. J. M. Bacon, and, under the auspices of the Aëro Club, by the Hon. C. S. Rolls. But for the use of balloons on any considerable scale these islands are not very suitable. It will hardly yet be forgotten that some years ago an attempt to pursue scientific investigation in this manner resulted in the loss of a valuable life. Work with kites even is not without its dangers, but it is satisfactory to note that the Royal Meteorological Society has taken up this mode of invest'gating the upper atmosphere, and has not only moved 1 je British Association to devote a sum of money for the purpose, but has secured the active interest of the president of the Society, Mr. W. H. Dines, in the undertaking. The British Isles occupy such an exceptional position with regard to the passage of weather changes from the Atlantic Ocean that the results of a properly directed inquiry of this character can scarcely fail to throw important light on many meteorological questions.

One of the results of the Congress of Meteorologists at Paris in 1900 was an international arrangement for the simultaneous exploration of the upper air in the various countries of Europe by means of unmanned balloons carrying self-recording instruments. An ascent was to be made on a fixed day in the first week of each month. Prof. Hergesell, of Strassburg, chairman of the Aëronautical Committee of the International Conference, undertook the collection and the working out of the results. The ascents have been regularly carried out and brief reports have appeared in the Meteorologische Zeitschrift. In this country Mr. P. Y. Alexander, of Bath, has carried out ascents of unmanned balloons on some of the appointed days, and has made provision for observations in manned balloons by Mr. Spencer. With the balloon observations are associated observations of clouds. We have no system of systematic measurement of cloud movements, but in connection with the balloon ascents the following observatories have furnished eye observations of the form and motion of clouds on the days of the ascents and the preceding and following days, viz. Greenwich, Kew, Oxford, Bidston, : Stonyhurst, Rousden, Falmouth, Glasgow, Aberdeen and Valencia. The returns have been sent to the Meteorological Office to be forwarded to Prof. Hergesell. The details of the ascents of November 8, I900 (the tenth of the whole series of international ascents) have already been published, and they show in a very effective manner the initial increase of temperature with height in the region of the anticyclone which covered the continental stations, Paris, Strassburg, Berlin, Vienna and St. Petersburg, at which ascents took place. Inversions of temperature are also very marked in the discussion of the Vienna observations for the ascent of January Io by J. Valentin in the Meteorologische Zeitschrift for June.

For meteorological purposes balloons will be much more serviceable when the means for converting them from aërostats into airships are perfected. It is fifteen years since Commandant Renard, who with his brother has been so active in all that concerns military ballooning in France, published his lecture, "Sur la Navigation Aérienne," before the Société de Secours des Amis des Sciences, in which he lays down with true French clearness the dynamical conditions for the airship as distinguished from the aerrostat. The publication is illustrated with a picture of an airship corresponding very closely with those of the airship of $M$. Santos Dumont that have attracted so much public attention within the last few months. At present airships are at best fair-weather vessels, and fair weather is a dull subject for meteorologists.

W. N. SHAW.

\section{GUN-SIGHTS FOR LARGE AND SMALL ORDNANCE.}

J $\mathrm{P}$ to quite recent times but little has been done by those interested in gunnery to improve in a really practical way the method of aiming either a rifle or gun. The usual method of aiming is much the same as that employed long ago in using the mediæual crossbow. The object aimed at, the fore-sight and the back-sight, are brought into line by the eye of the marksman, always with this defect, viz., that the eye is out of focus with respect to two of the points mentioned when focussed on the third. We know well that, if we fix our attention on a distant object, our eye will automatically focus itself on that distant object ; and only an indistinct image of the foresight will be present. Again, should we focus the eye on the fore-sight, then the object aimed at will not be clearly seen. This is also true in an accentuated manner with respect to the back-sight, since it is nearer to the eye than the fore-sight. The operation of thus aiming, even in the best circumstances of light, is obviously unsatisfactory.

The gun-sight problem has been attacked by several leading experimentalists, and in the majority of cases some apparatus in which lenses are employed has been used. An early form of optical gun-sight consisted of a small telescope attached to the gun, the telescope being furnished with an eye-piece and cross-lines or webs, similar to those used in the surveyor's level or theodolite. This telescope is attached to the rifle by a joint at one end, the other end being raised or depressed to suit the range by means of a milled headed micrometer screw. The telescope-sight has been applied to field and other guns, and to it has been added an inclinometer, so that an angle inclination either above or below the horizontal line can be given to the gun.

Objections have been raised to the telescope-sight, and it has been urged that the field is limited, so that it is not easy to "pick up" the object to be hit, and that the object appears to be moving with a speed greater than its real one, also that when heavy charges of gunpowder are used, and the recoil is considerable, there is a risk of the eye of the marksman being injured by the cap of the eye-piece when it is driven back, and also that the adjustment of the telescope may be thrown out, by the concussion on firing the piece. With respect to the first objection, in the case of a man with short sight, the telescope-sight is of great use since it enables him to see the object as clearly as a man with normal vision. Whe the telescopic nethod is used for laying field guns, the

NO. I 680 , VOL. 65$]$ 
sight is placed in a geometric bracket for aiming and removed immediately before the gun is fired, as otherwise it would be injured by concussion.

The gun-sight invented by Sir Howard Grubb, F.R.S., is free from imperfections inherent in the old form of telescope-sights used on rifles. The new instrument is called by him the "Collimating-telescope Gun-sight," and a paper on the subject in the Transactions of the Royal Dublin Society (March 20, 1901) at once shows what considerations led up to the invention of the new form of gun-sight. In it the inventor pictures an ideal sighting arrangement thus :- $\mathrm{He}$ imagines a ring or cross to be carried on a very long, weightless and rigid rod forming a prolongation of the gun-barrel, so that the ring or cross would always be situated in the prolongation of the axis of the gun, and each shot, if the trajectory were quite flat, would pass through the ring. The inventor goes on to show that such an ideal rod might be realised by using a fine beam of light, which might be projected on to the object and indicate the direction of the axis of the gun. This end is in practice obtained by projecting a "virtual" image upon the object on which the gun is aimed. By means of the gun-sight now to be described a "virtual" image of a small bright cross or circle is projected on to the object aimed at. The earliest form

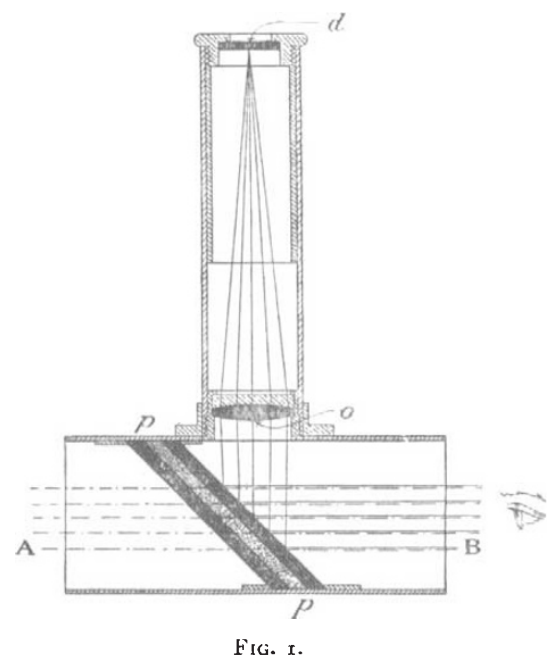

in which the gun-sight was made 1 shown in Fig. 1 , in which the object aimed at is viewed through a piece of tube of square section $A B$, open at each end, a piece of parallel glass, $p p$, being fixed at an angle of $45^{\circ}$ to the axis of the tube. In another tube at right angles to the former a diaphragm $d$ is fixed, made of glass coated with an opaque. substance, through which fine lines are scratched in the pattern of a cross or star or circle. $o$ is an achromatic lens, and the distance between the cross and the lens equals the principal focus of the lens; so that rays of light passing through the cross, on reaching the lens, are by it made parallel, they are then reflected by the plates $\not p$ as parallel rays to the observer's eye, and the observer sees a "virtual" image of the cross coinciding with the object aimed at, and apparently at the same distance as the object. This optical device causes the cross to be seen sharply defined, with the same focussing of the eye required for viewing the distant object, and all straining of the eye, as is the case in the old system, vanishes; also there is no parallax, and therefore the eye need not be kept in one position. This "virtual" image of the cross, forms a fore-sight projected to a long distance in front of the rifle, as if it were carried upon an invisible, imponderable and inflexible prolongation of the barrel. This form of apparatus not being of convenient shape for practical use, the gun-sight eventually assumed the form shown in Fig. 2, in which $d$ is the cross, which is reflected by the mirror $C$, on to a curved glass surface $r$, cuated with a very thin layer of galena, the ray is reflected as a parallel beam to the eye, and at the same time the

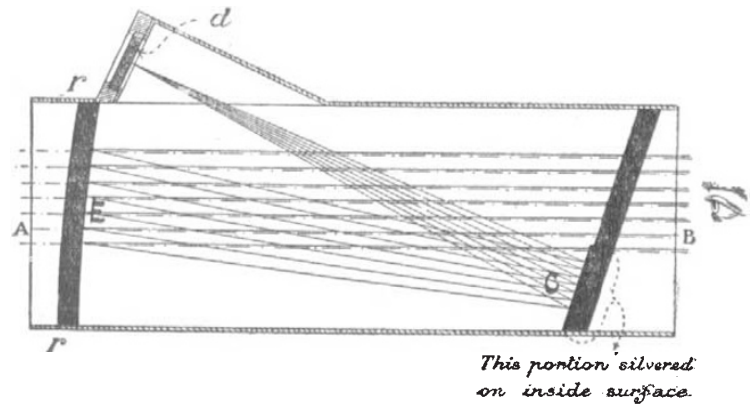

Fig. 2.

object is seen through the coated surface. The radius of curvature of $r r$ equals twice the distances $d \mathrm{C}$ and $\mathrm{CE}$. When the eye is placed anywhere near the axis of the gun-sight the bright cross is seen superposed on the object, and the usual effort required in the attempt to focus two objects not at the same distance is entirely avoided. The photograph (Fig. 3), taken by a camera

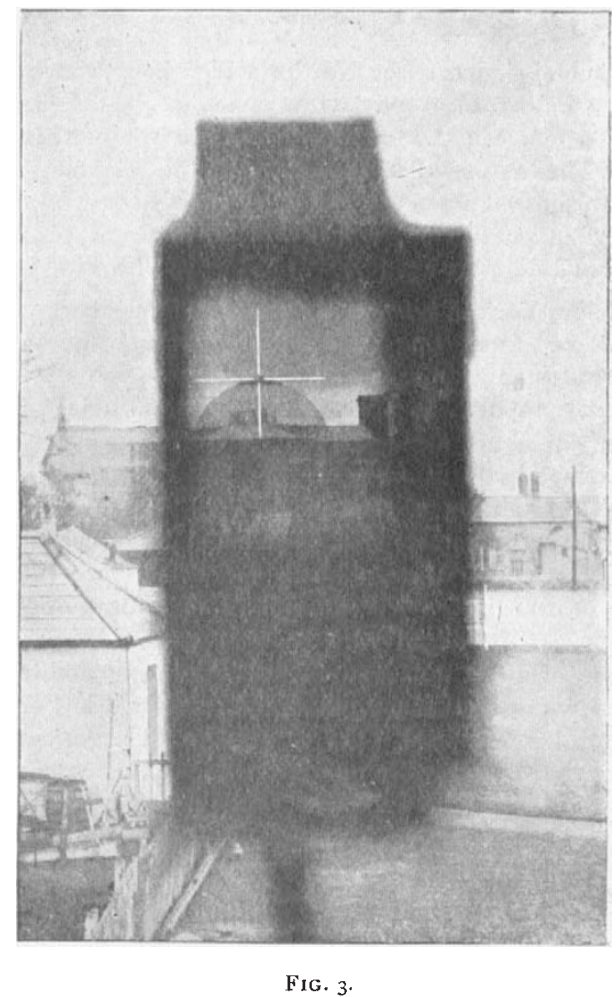

placed behind the gun-sight and focussed on the dome of a building, shows how perfectly the cross coincides with the object, both the object and cross being in perfect focus.

The gun-sight is mounted on a graduated metal arc attached to the rifle, by means of which it is adjusted for various ranges. The sight may be used either with or without a telescope or monocular, since the same focus

NO. I680, VOL. 65] 
suits both the object and the image of the cross; also by cutting divided scales on the diaphragn glass, useful estimates may be made of both distance and windage.

In an experiment made on a gun-sight, kindly lent to the writer of this article by Sir Howard Grubb, good shooting was made on a white target when it was dusk, and an ordinary fore-sight could not be seen, by illuminating the cross, by a minute reflected side-light, entirely shielded from view from the locality of the target. This form of gun-sight could thus be used, in certain circumstances, long after the ordinary fore-sight had become invisible.

A very small diminution of light coming from the object is produced by the deposit of galena on the mirror, but it is so minute, that it practically causes no inconvenience to the marksman when aiming a rifle at a distant object.

\section{NOTES.}

Prof. Albert Gaudry has been elected vice-president of the Paris Academy of Sciences for the year 1902.

THE Symons Gold Medal of the Royal Meteorological Society will be presented to Dr. A. Buchan, F.R.S., at the annual meeting of the Society to be held on Wednesday, January I 5.

WE regret to see that Prof. Virchow met with an accident on Saturday evening while alighting from an electric. tramway car in Berlin. The injuries are described as a wrench to the hip joint and various contusions on the leg;. in consequence of which Prof. Virchow will for a long time be confined to his room.

THE Commissioners of the Northern Lighthouses have decided to adopt wireless telegraphy as a means of establishing communication between the mainland and certain of their lighthouses. The first installation will be at the Flannan Islands, which are situated about sixteen miles outside the west coast of Lewis. The installation, which will be made in conjunction with Lloyd's shipping agency, will be on the Marconi system.

THE New York Electrical Review for December 2I, I90I, contains some interesting particulars concerning Mr. Marconi's recent success in transmitting signals across the Atlantic by wireless telegraphy. It appears that before leaving England Mr. Marconi made arrangements for having the letter "S" signalled repeatedly at frequent intervals for three hours daily from his transmitting station at Poldhu. The power of the transmitting arrangements in Cornwall had been increased considerably since Mr. Marconi had succeeded in bridging a distance of 200 miles. At St. John's there was only a temporary station, the aërial wire being suspended from a kite at an altitude of about 400 feet. The transmitting and receiving arrangements were carefully tuned, the receiver being of a new type recently developed. On December I4 a succession of "S's" was received with unmistakable distinctness, and a similar series was received on the next day, but this time not quite so distinctly. Mr. Marconi attributes the variability partly to fluctuations in the height of the kite, bad weather prevailing at the time, and partly to the fact that the receiver had to be extremely sensitive and required constant adjustment. The erection of a permanent station in America and the increase in the power of the transmitters should remedy these two defects. It is now almost exactly I5o years since Franklin's classical experiment with a kite, which now, therefore, figures for a second time as important in the history of electrical development.

THE following news from Baron Toll's Arctic Expedition was received by the chief of the Central Meteorological Observatory at St. Petersburg, in a telegram, dated Yakutsk, December 4/17:-

No. I 680 , vou. 65$]$
“On September $11 / 24$ caught by winter in Nerpichiya Bay, $75^{\circ} \mathbf{2 2}^{\prime}$ N. and $137^{\circ} 16^{\prime}$ (E. longitude). From November I have opened meteorological station, with hourly observations. All right, all well. Sending greetings to Central Observatory. Zarya, October 25 (November 7), I901." It will be remembered that the expedition started last summer on board the steamer Zarya with the intention of wintering somewhere on the Arctic coast of Siberia; so as to Degin in the spring the exploration of the New Siberia Islands.

THE Russian newspapers publish the following official tele. gram, dated Yakutsk, December 28 :- "The expedition which was sent out by the Academy of Sciences; under the zoologist Hertz; to examine the mammoth remains discovered in the district of Kolymsk, has reached Sredne Kolymsk, after a very difficult journey, bringing the mammoth with it. The animal was a male and apparently middle-aged. Its skeleton and skin have been preserved nearly intact. The tail was short and covered with long hair. In the stomach, between the teeth and on the tongue, remains of undigested food were found. The different parts of the mammoth have been conveyed to St. Petersburg in a frozen condition."

THE eleventh Congress of Russian Naturalists and Physicians was opened at St. Petersburg on January 2 by the Grand Duke Alexander of Oldenburg. The number of people anxious to take part in the Congress was very large, more than $3250 \mathrm{mem}$ bers' tickets having been taken on the day of opening. The Minister of Public Instruction has given a sum of 500 . to defray the expenses of the Congress, and both the Municipality of St. Petersburg and the University have contributed large sums for the same purpose. At the first general meeting of the Congress, the president (Prof. Menschutkin) spoke about the foundation of a Russian Association for the Advancement of Science, which would hold regular congresses every year. This proposal was accepted by a congress held eleven years ago ; but the Ministry of Public Instruction was hostile to the idea, and only now the new Minister, General Vannovsky, has agreed not to oppose it. At the same general meeting Prof. S. M. Lukianoff delivered an address on the limits of cytological research under normal and pathological conditions, in which he endeavoured to establish the limits of psycho-physiology; and Prof. N. A. Umoff delivered a brilliant address on a physico-mechanical model of living matter.

THREE pleasure cruises have been arranged by our con. temporary the Revue genérale des Sciences to take place this year. At Easter there will be an excursion to Greece and the Greek Isles, in charge of M. C. Homolle, director of the French School at Athens, and M. G. Fougères, of the University of Paris. At the end of September there will be a trip to Syria and Palestine, directed by M. C. Diehl, and in November an excursion will be made to Egypt, up to the second cataract, under the direction of a well-qualified Egyptologist.

ON Tuesday next, January I4, Prof. A. Macfadyen will deliver as the Royal Institution the first of a course of six lectures on "The Cell, its means, of Offence and Defence, Immunity." On Thursday, January 16, Dr. A. S. Murray will begin a course of three lectures on "Recent Excavations at Delphi and in the Greek Islands." The "Friday evening discourse on January I 7 will be delivered by Lord Rayleigh, his subject being "Interference of Sound." On Jànuary 24 Mr. H. G. Wells will give a discourse on' "The Discovery of the Future," and on January 3 I Prof. A. Crum Brown one on the "Ions of Electrolysis."

THE Decimal Association has sent us a list of I 72 members of Parliament who have notified their approval of the compulsory adoption of the metric system of weights and measures into Great 